\title{
Effect of centrifuge test on blood serum lipids index of cadet pilots
}

\author{
Zbigniew Wochyński', Krzysztof Kowalczuk², Marek Kłossowski², Krzysztof A. Sobiech ${ }^{3}$ \\ ${ }^{1}$ Department of Physical Education, Polish Air Force Academy, Dęblin, Poland \\ ${ }^{2}$ Aeromedical Training Division, Military Institute of Aviation Medicine, Warsaw, Poland \\ ${ }^{3}$ Department of Basic Physiotherapy, Academy of Physical Education, Wrocław, Poland \\ Wochyński Z, Kowalczuk K, Kłossowski M, Sobiech KA. Effect of centrifuge test on blood serum lipids index of cadet pilots. Ann Agric Environ \\ Med. 2016; 23(1): 1-5. doi: 10.5604/12321966.1184693
}

\begin{abstract}
Introduction and objective. This study aimed at investigating the relationship between the lipid index (WS) in the examined cadets and duration of exposure to $+\mathrm{G} z$ in the human centrifuge.

Materials and methods. The study involved 19 first-year cadets of the Polish Air Force Academy in Dęblin. Tests in the human centrifuge were repeated twice, i.e. prior to (test I) and 45 days after (test II). After exposure to $+\mathrm{Gz}$, the examined cadets were divided into 2 groups. Group I $(\mathrm{N}=11)$ included cadets subjected to a shorter total duration of exposure to $+\mathrm{Gz}$, while group II $(\mathrm{N}=8)$ included cadets with a longer total duration of exposure to $+\mathrm{Gz}$. Total cholesterol (TC), high density lipoprotein (HDL), triglycerides (TG), and apolipoproteins $A$ and $B$ were assayed in blood serum prior to (assay $A$ ) and after (assay B) both exposures to $+\mathrm{Gz}$. Low density lipoprotein (LDL) level was estimated from the Friedewald formula. WS is an own mathematical algorithm.

Results. WS was higher in group II, assay A - 10.0 and B - 10.08 of test I in the human centrifuge than in group I where the WS values were 6.91 and 6.96, respectively. WS was also higher in group II in assay A - 10.0 and B-10.1 of test II in the human centrifuge than in group I -6.96 and 6.80 , respectively.

Conclusions. The higher value of WS in group II, both after the first and second exposure to $+\mathrm{Gz}$ in human centrifuge, in comparison with group I, indicated its usefulness for determination of the maximum capability of applying acceleration of the interval type during training in the human centrifuge.
\end{abstract}

\section{Key words}

Lipid index WS, human centrifuge, serum, total duration of exposure to $+\mathrm{Gz}$, anti-G straining L-1 maneuver

\section{INTRODUCTION}

Human centrifuge training and $+\mathrm{Gz}$ tolerance testing are essential components of the Air Force Academy cadet training. The Lipid Index (WS) assessment of body fitness, used by Wochyński and Sobiech, is one of the factors to estimate capability to perform human centrifuge manoeuvers. Skill of muscle straining maneuvers, dependent on the existing endurance level [1] and muscle strength [2] of an isometric character, is of importance in such training. The most frequently used body loads during exposure to $+\mathrm{Gz}$ in the human centrifuge is an acceleration profile, being a variation of interval-type acceleration.

The authors' long experience in clinical trials and physical fitness studies in pilots suggests the necessity to use reliable indices (markers) of the body load. This load may be evaluated with already known biochemical markers being of diagnostic value to assess human body adaptation to physical exercise. Such markers include, among other, parameters of lipid metabolism, such as: apolipoprotein $A_{1}$ (Apo-A $A_{1}$ ) apolipoprotein B (Apo-B), triacylglycerols (TAG), low density lipoprotein (LDL), and high density lipoprotein (HDL). Physical activity and diet exert an effect on changes in their values [3]. WS, which was tested in view of adaptation to physical exercise in athletes' training, considering physical exercise [4] in soldiers both physically active and inactive

Address for correspondence: Zbigniew Wochyński, Department of Physical Education, Polish Air Force Academy, Dywizjonu 303, 08-521 Dęblin, Poland e-mail: zbigniew.wochynski@op.pl

Received: 15 October 2013; accepted: 20 October 2014
$[4,5]$, long distance runners prior to and after runs of various distances [6].

WS also was used in monitoring hormone replacement therapy in women [7]. A significant feature of the WS is an increase in its value when physical fitness increases, and its decrease indicating a drop of physical fitness [5].

\section{OBJECTIVES}

In this study, an attempt was made to evaluate the body load of cadets with the stimulus being a variation of the intervaltype acceleration characteristics during tests in the human centrifuge, to answer the following questions:

1. Has WS diagnostic value in the differentiation of cadets' physical fitness versus a total time of exposure to $+\mathrm{Gz}$ during the test in the human centrifuge?

2. Is there a correlation between WS value in the examined cadets and total duration of exposure to $+\mathrm{Gz}$ during the tests in the human centrifuge?

\section{MATERIALS AND METHOD}

The study involved 19 cadets of the first class of the Air Force Academy in Dęblin, Poland, aged 19 years, on average, with the speciality of aircraft pilot (Tab. 1). Cadets were divided into 2 groups after completion of test I, depending on the total duration of exposure to $+\mathrm{Gz}$. Cadets who achieved less than $300.5 \mathrm{sec}$ (average value of duration) of the total duration of exposure to $+\mathrm{Gz}$ were assigned to group I $(n=11)$, while the 
remaining cadets were assigned to group II $(n=8)$. Group I included cadets of the total exposure to $+\mathrm{Gz}$ amounting to $254.2 \mathrm{sec}$., while group II included cadets whose total exposure to $+\mathrm{Gz}$ was longer. Exposure to $+\mathrm{Gz}$ of $254.2 \mathrm{sec}$. was the highest in group I.

The authors obtained permission to perform the study from the Ethical Commission of the Biomedical Research Studies at the Military Institute of Aviation Medicine. (Decision No. 03/2008 of 21.04.2008).

Methods. Blood samples for examination were drawn twice, from the elbow vein following both exposures to $+\mathrm{Gz}$, at the beginning (test I), and after a 45 -day period of training (test II).

Assay A: immediately prior to exposure to $+\mathrm{Gz}$.

Assay B: immediately after exposure to $+\mathrm{Gz}$.

The following lipid parameters were assayed in the collected blood samples:

Apo-A and Apo-B with immunoturbimetric technique [8], using reagents by OLYMPUS and auto-analyzer OLYMPUS AV400, TAG with enzymatic technique, HDL with precipitation technique, and LDL was estimated from Friedewald formula. Enzymatic-oxidase method was used to assay total cholesterol (TC).

WS was calculated from the following formula:

$$
W S=\frac{\left(H D L+\frac{T A G}{6}\right) \times \frac{A p o-A_{1}}{30} \times 10}{\left(L D L+\frac{T A G}{5}\right) \times \frac{A p o-\mathrm{B}}{20}}
$$

where: WS - Wochyński and Sobiech lipid index;

HDL - high density lipoprotein $(\mathrm{mg} / \mathrm{dL})$

LDL - low density lipoprotein $(\mathrm{mg} / \mathrm{dL})$;

TAG - triacylglycerols (mg/dL);

' 6 ' - percent TAG content in HDL lipoprotein;

' 5 ' - percent TAG content in LDL lipoprotein;

Apo- $A_{1}$ - apolipoprotein $A_{1}(\mathrm{mg} / \mathrm{dL})$;

Apo-B - apolipoprotein B (mg/dL);

' 30 ' - percent Apo-A content in HDL lipoprotein; '20' - percent Apo-B content in LDL lipoprotein;

10 - multiplier.

Procedure and design. Exercises within a directed educational programme were performed for 2 hours, 3 times a week for 45 days. This programme aimed at performing systemic exercises with emphasis on isometric muscle training. The muscle groups involved in the anti-G straining L-1 manoeuver were strained. Based on EEM measurements, these muscles included the latissimus dorsi, intercostal muscle, buccinator muscle, sternocleidomastoideus, diaphragm and pectoralis major [9], as well as the rectus femoris muscle, abdominal rectus muscle, and spine erector [10].

Cadets were provided with the same conditions of living and diet during the whole period of education. They were provided with a standard diet according to the principles of the institutional nutrition. Calorie value of the daily diet was $4,500 \mathrm{kcal}$, including $150 \mathrm{~g}$ (30\%) fat, $112.5 \mathrm{~g}$ (10\%) protein, and $675 \mathrm{~g}(60 \%)$ carbohydrates.

Examined cadets were exposed to $+\mathrm{Gz}$ in the human centrifuge twice, with variation of the interval-type acceleration of isometric training characteristics. During the exposure, acceleration was $+3.5 \mathrm{Gz} / \mathrm{s}$, intervals (acceleration- pause) were $15 \mathrm{sec}$. The authors assumed that the loading programme would be realized by the examined cadets and measured according their physical capabilities by the number reaching the peak of $+6 \mathrm{Gz}$ (Fig. 1, Tab. 1). Total time of exposure to $+\mathrm{Gz}$ achieved in tests I and II depended on the cadets-pilots maximum exercise capabilities. The decision about the test completion was made by the cadets themselves.

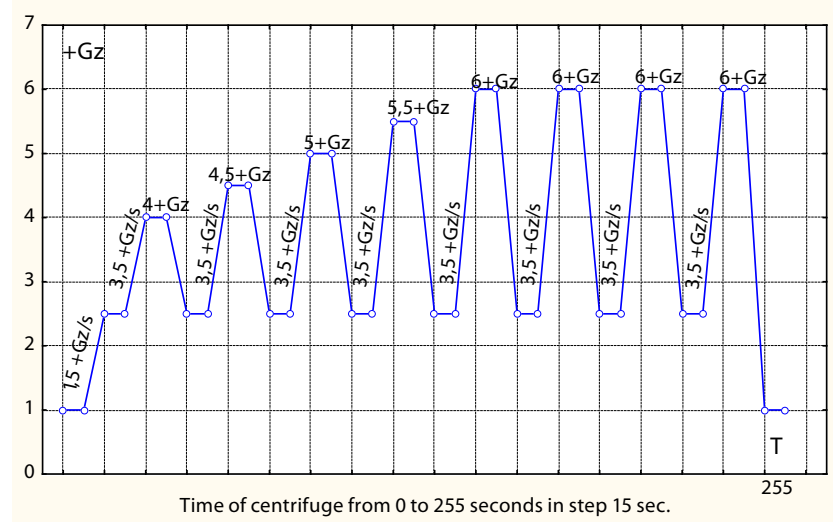

Figure 1. Graph of loading profile

Statistical analysis. Mean and standard deviation of all parameters were calculated by statistical analysis. Differences in lipid parameters prior to and after centrifugation in both groups were calculated with t-test for depended groups, while differences between groups - with t-test for independent groups. Pearson correlation coefficient (r-Pearson) was used to calculate correlation between total centrifugation time and lipid parameters in the investigated groups. Computer programme STATISTICA 9.0 was used for statistical analysis of the obtained results. Differences were considered significant when the calculated p-value was less than 0.05 .

\section{RESULTS}

A statically insignificant difference between both groups in relation to the age, body weight, height and BMI was observed during tests I and II (Tab. 1).

Table 1. Age, somatic features, and physical parameters in examined groups

\begin{tabular}{|c|c|c|c|c|}
\hline Index & Test & Group I (N-11) & Group II (N-8) & $\mathrm{p}$ Value \\
\hline \multirow{2}{*}{ Body weight (kg) } & 1 & $71.9 \pm 8.10$ & $71.5 \pm 5.10$ & NS \\
\hline & II & $71.4 \pm 8.04$ & $71.3 \pm 5.06$ & NS \\
\hline \multirow{2}{*}{ Height (m) } & I & $1.78 \pm 0.04$ & $1.79 \pm 0.04$ & NS \\
\hline & II & $1.78 \pm 0.04$ & $1.79 \pm 0.04$ & NS \\
\hline \multirow{2}{*}{$\mathrm{BMI}\left(\mathrm{kg} \cdot \mathrm{m}^{-2}\right)$} & I & $22.57 \pm 2.05$ & $22.26 \pm 1.44$ & NS \\
\hline & II & $22.53 \pm 2.01$ & $22.23 \pm 1.40$ & NS \\
\hline \multicolumn{2}{|c|}{$\begin{array}{l}\text { Total duration of } \\
\text { exposure to }+\mathrm{Gz} \text { in test I }\end{array}$} & $238.30 \pm 26.83$ & $386.16 \pm 27.41$ & $<0.001$ \\
\hline \multicolumn{2}{|c|}{$\begin{array}{l}\text { Total duration of } \\
\text { exposure to +Gz in test II }\end{array}$} & $262.74 \pm 95.5$ & $399.95 \pm 0.13$ & $<0,001$ \\
\hline \multicolumn{2}{|l|}{$\begin{array}{l}\text { No. of reached } \\
\text { peak }+6 \mathrm{Gz} \text { in test I }\end{array}$} & $3.63 \pm 0.67$ & $7.62 \pm 0.74$ & $<0,001$ \\
\hline \multicolumn{2}{|l|}{$\begin{array}{l}\text { No. of reached } \\
\text { peak }+6 G z \text { in test II }\end{array}$} & $4.27 \pm 2.61$ & $8.0 \pm 0.0$ & $<0,001$ \\
\hline
\end{tabular}

Mean $\pm S D ; p-$ value of difference significance; NS - no statistically significant; I - test I prior to the education programme; II - test II after education programme 
Table 2. Results of lipid parameters assayed in serum of group I and group II prior to and after exposure in tests I and II

\begin{tabular}{|c|c|c|c|c|c|c|c|}
\hline \multirow{2}{*}{ Parameter } & \multirow{2}{*}{ Test } & \multicolumn{2}{|c|}{ Group I $(\mathrm{N}=11)$} & \multicolumn{4}{|c|}{ Group II $(\mathrm{N}=8)$} \\
\hline & & Assay A & Assay B & p-Value & Assay A & Assay B & $\mathrm{p}$-Value \\
\hline \multirow{2}{*}{$\begin{array}{l}\mathrm{TC} \\
(\mathrm{mg} / \mathrm{dL})\end{array}$} & 1 & $183.1 \pm 31.1$ & $188.9 \pm 32.4$ & 0.10 & $157.7 \pm 24.9$ & $160.0 \pm 23.7^{\mathrm{d}}$ & 0.50 \\
\hline & ॥ & $201.1 \pm 32.3$ & $201.7 \pm 33.8$ & 0.88 & $157.5 \pm 20.2^{c}$ & $154.1 \pm 16.6^{\mathrm{e}}$ & 0.18 \\
\hline \multirow{2}{*}{$\begin{array}{l}\mathrm{HDL} \\
(\mathrm{mg} / \mathrm{dL})\end{array}$} & 1 & $50.8 \pm 9.1$ & $54.0 \pm 8.7$ & $<0.01$ & $52.2 \pm 9.9$ & $54.7 \pm 9.7$ & $<0.05$ \\
\hline & $\|$ & $53.0 \pm 9.8$ & $56.0 \pm 10.5$ & $<0.001$ & $51.1 \pm 7.2$ & $52.8 \pm 6.7$ & $<0.01$ \\
\hline (mg/dL) & $\|$ & $106.9 \pm 34.2$ & $115.5 \pm 33.4$ & $<0.001$ & $78.0 \pm 15.1^{\mathrm{a}}$ & $83.3 \pm 12.8^{\mathrm{d}}$ & 0.25 \\
\hline \multirow{2}{*}{$\begin{array}{l}\text { TAG } \\
(\mathrm{mg} / \mathrm{dL})\end{array}$} & 1 & $147.0 \pm 70.0$ & $138.9 \pm 107.8$ & 0.70 & $124.1 \pm 103.8$ & $118.2 \pm 40.5$ & 0.84 \\
\hline & II & $159.7 \pm 75.6$ & $150.3 \pm 81.1$ & 0.77 & $141.6 \pm 128.3$ & $89.5 \pm 44.4$ & 0.13 \\
\hline \multirow{2}{*}{$\begin{array}{l}\text { Apo-A } \\
\text { (mg/dl) }\end{array}$} & 1 & $140.0 \pm 12.7$ & $142.7 \pm 10.7$ & 0.18 & $145.3 \pm 13.0$ & $145.7 \pm 11.2$ & 0.85 \\
\hline & ॥ & $148.1 \pm 12.6$ & $151.4 \pm 14,3$ & 0.08 & $143.5 \pm 5.3$ & $144.3 \pm 6,3$ & 0.46 \\
\hline (mg/dL) & ॥ & $93.4 \pm 18.7$ & $96.0 \pm 20.9$ & $<0.05$ & $70.6 \pm 13.2^{b}$ & $68.8 \pm 11.7^{e}$ & 0.11 \\
\hline \multirow{2}{*}{ WS } & 1 & $6.9 \pm 3.4$ & $7.0 \pm 3,6$ & 0.83 & $10.0 \pm 3.9$ & $10.8 \pm 4.5$ & 0.18 \\
\hline & II & $7.0 \pm 3.7$ & $6.8 \pm 3,7$ & 0.37 & $10.0 \pm 2.7$ & $10.1 \pm 3.2$ & 0.88 \\
\hline
\end{tabular}

Assay A - immediately before exposure to +Gz; assay B -immediately after exposure to +Gz; I-test l prior to education programme; ll-test ll after education programme; mean + SD; a - difference statistically significant at $\mathrm{p}<0.05$ in comparison with values in assay $A$ of group $\mathrm{I}^{\mathrm{b}}{ }^{\mathrm{b}}$ - difference statistically significant at $\mathrm{p}<0.01$ in comparison with values in assay $A$ of group $\mathrm{I}^{\mathrm{c}} \mathrm{c}-$ difference

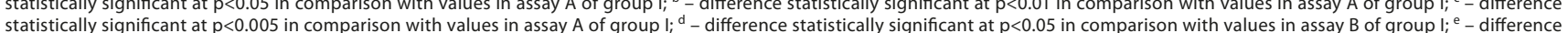
statistically significant at $p<0.005$ in comparison with values in assay A of group ;
statistically significant at $p<0.005$ in comparison with values in assay B of group I;

The obtained results after test I in group I showed a statistically significant increase in HDL at $\mathrm{p}<0.01$ in assay $\mathrm{B}$, compared with assay $\mathrm{A}$. The remaining differences were statistically insignificant (Tab. 2). Total duration of exposure to $+\mathrm{Gz}$ in the group I - $238.3 \mathrm{sec}$. (Tab. 1).

After the test II, in group I statistically significant increase in $\mathrm{HDL}$ and LDL values at $\mathrm{p}<0.001$, Apo-B at $\mathrm{p}<0.05$ were noted in assay $\mathrm{B}$ in comparison with assay $\mathrm{A}$. The remaining differences are statistically insignificant (see Table 2). Total duration of exposure to $+\mathrm{Gz}$ was $262.6 \mathrm{sec}$.(see Table 1 ).

The results obtained after test I in group II showed a statistically significant increase in HDL at $p<0.05$ in assay $\mathrm{B}$, compared with assay $\mathrm{A}$. The remaining differences were

Table 3. Correlation $r$ - Pearson between lipid parameters and WS with total duration of exposure to $+\mathrm{Gz}$ in groups I and II in test I and test II

\begin{tabular}{|c|c|c|c|c|c|}
\hline \multirow{3}{*}{ Parameter } & \multirow{3}{*}{ Test } & \multicolumn{2}{|c|}{ Group I $(\mathrm{N}=11)$} & \multicolumn{2}{|c|}{ Group II (N=8) } \\
\hline & & Assay A & Assay B & Assay A & Assay B \\
\hline & & r-Value & r-Value & r-Value & r-Value \\
\hline \multirow{2}{*}{$\begin{array}{l}\mathrm{TC} \\
(\mathrm{mg} / \mathrm{dL})\end{array}$} & I & 0.05 & 0.19 & 0.12 & -0.16 \\
\hline & II & -0.14 & 0.009 & -0.58 & -0.34 \\
\hline \multirow{2}{*}{$\begin{array}{l}\mathrm{HDL} \\
(\mathrm{mg} / \mathrm{dL})\end{array}$} & 1 & -0.03 & 0.009 & 0.66 & 0.57 \\
\hline & II & 0.22 & 0.24 & 0.44 & 0.45 \\
\hline \multirow{2}{*}{$\begin{array}{l}\text { LDL } \\
(\mathrm{mg} / \mathrm{dL})\end{array}$} & 1 & 0.07 & 0.10 & -0.28 & -0.25 \\
\hline & II & 0.07 & -0.04 & 0.06 & -0.24 \\
\hline \multirow{2}{*}{$\begin{array}{l}\text { TAG } \\
(\mathrm{mg} / \mathrm{dL})\end{array}$} & 1 & -0.006 & 0.11 & 0.03 & -0.54 \\
\hline & II & -0.30 & -0.04 & -0.62 & -0.64 \\
\hline \multirow{2}{*}{$\begin{array}{l}\text { Apo-A } 1 \\
(\mathrm{mg} / \mathrm{dL})\end{array}$} & 1 & -0.21 & -0.16 & $0.72^{\mathrm{a}}$ & 0.44 \\
\hline & II & 0.11 & 0.05 & 0.02 & 0.44 \\
\hline \multirow{2}{*}{$\begin{array}{l}\text { Apo-B } \\
\text { (mg/dL) }\end{array}$} & 1 & 0.04 & 0.12 & -0.14 & -0.27 \\
\hline & II & -0.15 & -0.14 & -0.65 & -0.52 \\
\hline \multirow{2}{*}{ WS } & 1 & -0.05 & -0.05 & 0.44 & 0.35 \\
\hline & ॥ & 0.14 & 0.24 & 0.62 & 0.65 \\
\hline
\end{tabular}

I - test I prior to education programme; II - test II after education programme; ${ }^{\text {a }}$ - correlation statistically significant at $p<0.05$. statistically insignificant (Tab. 2). Total duration of exposure to $+\mathrm{Gz}-386.16 \mathrm{sec}$. (Tab. 1 ).

After test II in group II, a statistically significant increase in $\mathrm{HDL}$ at $\mathrm{p}<0.01$ was noted in assay $\mathrm{B}$, compared with assay A. The remaining differences were statistically insignificant (Tab. 2). Total duration of exposure to $+\mathrm{Gz}-399.95 \mathrm{sec}$. (Tab. 1).

The results obtained after tests I and II conducted on groups I and II were compared. Assay B of test I showed a decrease in the concentration of values $\mathrm{TC}$ at $\mathrm{p}<0.05$ in group II, compared to group I. No marked differences of the mean values for both groups were found in the remaining parameters (Tab. 2).

Assay A of test II showed a statistically significant decrease in the concentration of values TC at $\mathrm{p}<0.005, \mathrm{LDL}$ at $\mathrm{p}<0.05$, Apo-B at $\mathrm{p}<0.01$, in group II, compared with group I. The remaining differences were statistically insignificant (Tab. 2).

Assay B of test II showed a statistically significantly decrease in the concentration values TC at $\mathrm{p}<0.005$, LDL at $\mathrm{p}<0.05$, Apo-B at $\mathrm{p}<0.005$, in group II, compared with group I. The remaining differences were statistically insignificant (Tab. 2).

Correlations were shown between lipid parameters and WS and total duration of exposure to $+\mathrm{Gz}$ in groups I and II. In the group II in assay A of test I, statistically significant correlations were noted only between mean total duration of exposure to $+\mathrm{Gz}$ and $A$ po- $\mathrm{A}_{1}: \mathrm{r}=0.72$ at $\mathrm{p}<0.05$. In assay $\mathrm{B}$ of test $\mathrm{I}$, the correlations were statistically insignificant (Tab. 3). In the remaining assays A and B of test II, the correlations also were statistically insignificant. In group I, the correlations between lipid parameters and WS and mean total duration of exposure to $+\mathrm{Gz}$, were lower than in group II (Tab. 3). 


\section{DISCUSSION}

The results of assays performed at the beginning (test I) and at the end (test II) of the education programme showed that the time of physical training did not exert a significant effect on WS before and after exposure to $+\mathrm{Gz}$, nor on the change of the total duration of exposure to $+\mathrm{Gz}$ in both groups. Comparison of results obtained in group I and group II in tests I and II, i.e. at the start and at the end of physical training in assays A and B, showed lower WS values in group I, as opposed to group II where the tendency was the opposite. An insignificant increase in WS value in assay B of test I, in comparison with the baseline value in assay A, justifies the conclusion that the examined cadets were adequately fit and higher loads could be applied. If one is discussing body response to the applied stimulus in test I after exposure to $+\mathrm{Gz}$, WS values in test II could be analyzed in the category of adaptation level to the applied stimulus. A decreased WS value in comparison with its baseline value in group I in the test II may prove a lack of adaptation as a result of the load used in this group and significant body sensitivity to the applied stimulus.

It is worth noting the fact that in both groups a significant difference was observed in an increase in HDL value in test I and test II after exposure to $+\mathrm{Gz}$, compared with baseline values, whereas differences in Apo-A, TAG, and WS increase were not significant.

The significant increase in HDL values may be associated with an increase in the testosterone level in both groups. A positive correlation between blood serum testosterone and HDL was seen after 10 weeks of training. Simultaneously, it was observed that the training produces changes in these two parameters [11]. Positive correlation between HDL and $\mathrm{V}_{\mathrm{O} \text { max }}: \mathrm{r}=0.60$ at $\mathrm{p}<0.001$, and between Apo- $\mathrm{A}_{1}$ and $\mathrm{V}_{\mathrm{O} \max }: \mathrm{r}=0.60$ at $\mathrm{p}<0.001$ was noted [12].

Comparison of HDL and Apo-A concentration in assays $A$ and $B$ of test II in groups I and II suggests that the overall fitness of group I, in which HDL and Apo- $\mathrm{A}_{1}$ concentrations were higher, should be better than that in group II. However, total duration of exposure to $+\mathrm{Gz}$, being longer in group II than in group I in test II, contradicts this. A longer total duration of exposure to $+\mathrm{Gz}$ in group II was confirmed by WS, which showed a significant difference between both groups in assays $\mathrm{A}$ and $\mathrm{B}$, to the advantage of group II.

It seems that the adaptation of the cadets to the exercise of this type depended on the appropriate blood lipids profile and percent content of ST and FT muscular fibres. The study showed a positive correlation between total duration of exposure to $+\mathrm{Gz}$ and $\mathrm{HDL}$ and Apo- $\mathrm{A}_{1}$ concentrations, and an inverse correlation of blood serum TAG in group II in assay $\mathrm{B}$ of tests I and II. A relationship between type of muscular fibres and lipids was confirmed by the study of Tikkanen et al. [13], which showed a positive correlation between ST muscle fibres and HDL level: $r=0.57$ at $p<0.001$, Apo- $A_{1}: r=0.60$ at $\mathrm{p}<0.001$, and an inverse correlation with TAG: $\mathrm{r}=-0.43$ at $\mathrm{p}<0.001$. This means that the skeletal muscles participating in straining maneuvers, especially the ST-type fibres, exert an effect on blood lipid levels. WS, which positively correlates with duration of exposure to $+\mathrm{Gz}$, may be a useful diagnostic measure of the work of ST-type skeletal muscles. Comparing the obtained correlations between WS and total duration of exposure to $+\mathrm{Gz}$ in groups I and II, a higher endurance of group II in comparison with group I was noted.
Analysis of the obtained individual results in group I in test II, assay B showed that cadets with WS value below the mean of 6.8 had lower levels of endurance and strength as proved by their mean total time of exposure to $+\mathrm{Gz}(262.74$ sec). It is worth stressing that one cadet in group I achieved a much better result in test II in assay B than in test I. His results were similar to these achieved in group II; his WS was 12.93 and total duration of exposure to $+\mathrm{Gz}-399.9 \mathrm{sec}$. This confirms a rule observed in analysis between groups and within group I, that higher values of WS translate into higher physical fitness. Cadets of group I with WS above 6.80 and below the mean value of the total duration of exposure to $+\mathrm{Gz}-262.74 \mathrm{sec}$. are only enduring but not strong.

In group II, cadets with WS value above the mean of 10.1 and average total duration of exposure to $+\mathrm{Gz}$ of $399.95 \mathrm{sec}$., had both strength and endurance, compared with group I. It seems that the lower value of WS in group I may result from improper execution of anti-G straining manoeuver L-1 (lower number of engaged groups of muscles) or genetic distribution of FT- and ST-type muscular fibres.

In other studies of two groups of athletes performing stream-type systemic training (general mezocycle) and strength-speed training (special mezocycle), WS was measured prior to, immediately after, and 24 hours after the training, with an application of the identical training units. WS was significantly different in both groups of athletes after 24 hours following the end of the general and special mezocycles, in comparison with baseline values. A significant increase in WS value immediately after streamtype training, in comparison with its value at the end of the general mezocycle, and no significant changes immediately after strength-speed training, may suggest that the character of the exercise exerted a marked effect on WS in athletes. Stream-type training of athletes emphasized all motor features, using 416 exercises. The value of the WS was higher than that in athletes on the strength-speed training, where the number of muscles engaged in an effort was lower [4].

Lower WS in group I may result also from the predisposition to rapid movements, due to the higher number of FT-type muscular fibres engaged in anaerobic processes (metabolism of lactates). Studies by Wochyński et al. [14] showed that interval endurance-speed training significantly decreased HDL cholesterol and TAG in anaerobic lactic acid metabolism. This may explain the shorter total duration of exposure to $+\mathrm{Gz}$ in group I, compared with group II. Studies by Schele and Kaiser [15] confirm such a relationship. These authors, examining a vastus lateralis muscle sample, showed that an athlete with a higher number of FT-type muscular fibres was slower in running 2,000 m, and faster at the distance of $40 \mathrm{~m}$.

Shono et al. [16] showed a significant increase in the proportion of capillaries per one muscular fibre after lowintensity endurance training, in comparison with baseline value. Changes in this proportion inversely correlate with LDL/HDL In the presented study, the lower WS in group I than that in group II may also indicate lower blood vessels elasticity, associated with higher TC, LDL cholesterol, and Apo-B levels. In the current study, a significant increase in Apo-B was noted in group I in assay B of test II, compared with the value in assay A. Significant differences in Apo-B, LDL, and TC concentrations were found between the studied groups in assays $\mathrm{A}$ and $\mathrm{B}$ of test II.

Shono et al. [17], examining a sample of vastus lateralis skeletal muscle in men of $\mathrm{BMI}=22.7 \pm 2.5 \mathrm{~kg} / \mathrm{m}^{2}$, showed that 
the number of capillaries around type II(b) muscular fibres correlated inversely with blood serum LDL level. The number of capillaries per one muscle fibre, number of capillaries per surface, and around of each type of muscle fibres, correlated inversely with serum Apo-B. Moreover, the diffusion index of fibre type correlated positively with LDL and Apo-B. The results obtained by Shono et al. [17] indicate that the density of skeletal muscle capillaries and diffusion capacity are associated with lipid and apolipoprotein levels in both types of fibres.

It seems that the value of WS in group II in comparison with group I in the presented study may indicate that the examined cadets did not perform maximal isometric muscle contractions, which determine oxygen and energy substances supplied to the muscular cells, depending on the rate of intramuscular and intravascular pressures.

\section{CONCLUSIONS}

This study shows that WS has diagnostic value in differentiating the physical fitness of cadets during the test in the human centrifuge. Higher positive correlation between WS and total time of exposure to $+\mathrm{Gz}$ in group II, compared to group I, confirms the diagnostic value of this parameter in differentiating the cadets efforts and capabilities.

\section{REFERENCES}

1. Baldin UI, Myhre K, Tesch PA, Wilhelmsen U, Andersen HAT. Isometric abdominal muscle training and $\mathrm{G}$ tolerance. Aviat Space Environ Med. 1985; 56: 120-124.

2. Burton RR, Whinnery J E, Foster EM. Anaerobic energetic of the simulated aerial combat maneuver (SACM). Aviat Space Environ Med. 1987; 58: 761-767.

3. Wood PD, Stefanick ML, Williams PT, Haskell WL. The effects on plasma lipoproteins of a prudent weight-reducing diet, with or without exercise, in overweight men and women. New Eng J Med. 1991; 325: 461-466.

4. Wochyński Z, Sobiech KA, Majda J. Wskaźnik lipidowy (WS) w ocenie wydolności fizycznej. Nowiny Lekarskie. 2005; 1: 39-44 (in Polish).

5. Wochyński Z, Sobiech KA, Majda J. Ocena progu adaptacji wysiłkowej żołnierzy za pomocą wskaźnika lipidowego w aspekcie kwalifikowania do testów sprawności fizycznej. Lek Wojsk. 2001; 77: 218-221 (in Polish).

6. Wochyński Z, Sobiech KA, Majda J. The impact of long distance runs on soldier's lipids index (WS)" „International Congress on soldier's physical exercise perfomance”. Jyväskylä 2005: 135.

7. Karmowski A, Sobiech KA, Markuszewski M, Majda J, Łątkowski K, Karmowski, et al. Values of the hormone replacement therapy in the postmenopausal women. Adv Clin Exp Med. 2005; 14(4): 725-729.

8. Rita N, King ME. Immunoturbidimetric assays of apolipoproteins A, AI, AII, and B in serum. Clin Chem. 1986; 6: 957-961.

9. Chen H-H, Wu Y-C, Kuo M-D. An electromyographic assessment of anti-G straining maneuver. Aviat Space Environ Med. 2004; 75: 162-167.

10. Oksa J, Hamalainen O, Rissanen S, Myllyniemi J, Kuromen P. Muscle strain during aerial combat maneuvering exercise. Aviat Space Environ Med. 1996; 67: 1138-1143.

11. Frey MAB, Doerr BM, Srivastava LS., Glueck CJ. Exercise training sex hormones, and lipoprotein relationships in men. J Appl Physiol. 1983; 54: 757-762.

12. Olchawa B, Kingwell BA, Hoang A, Schneider L, Miyazaki O, Nestel P. et al. Physical fitness and reverse cholesterol transport. Arterioscler Thromb Vasc Biol. 2004; 24: 1-6.

13. Tikkanen HO, Härkönen M, Näweri H, Hämäläinen E, Elovainio R, Sarna S. et al. Relationship of skeletal muscle fiber type to serum high density lipoprotein cholesterol and apolipoprotein $\mathrm{A}_{1}$ levels. Atherosclerosis 1991; 90: 49-57.

14. Wochyński Z, Majda J, Sobiech KA. Zmiany wskaźników hematologicznych i biochemicznych u lekkoatletów pod wpływem treningu wytrzymałościowo - szybkościowego. Wych Fiz i Sport. 1998; 3: 39-47.

15. Schele R, Kaiser P. Running performance and muscle fibers types. In: Komi PV(ed.). Exercise and sport biology. Human Kinetics Publ. Champaign, Illinois 1982.pp.84-89.

16. Shono N, Urata H, Saltin B, Mizuno M, Harada T, Shindo M, et al. Effects of low intensity aerobic training on skeletal muscle capillary and blood lipoprotein profiles. J Atherioscler Thromb. 2002; 9: 78-85.

17. Shono N, Mizuro M, Nishida H, Higaki Y, Urata H, Tanaka H. et al. Decreased skeletal muscle capillary density is related to higher serum levels of low density lipoprotein cholesterol and apolipoprotein B in men. Metabolism 1999; 48: 1267-1271. 